\title{
O CUIDADO COMO AMOR EM HEIDEGGER
}

\author{
Care like Love in Heidegger's Thought \\ Cuidado como Amor en Heidegger
}

Marcos Aurélio Fernandes

\begin{abstract}
Resumo: O presente artigo procura compreender uma indicação dada por Heidegger a Medard Boss, segundo a qual "Sorge" (cura, cuidado) não pode ser diferenciada em contraposição ao amor, como fizera Binswanger, por ser o nome para a constituição extático-temporal do traço fundamental da presença (Dasein), ou seja, da compreensão do ser. O artigo analisa cada momento desta indicação e busca compreender em que sentido cuidado é, ontologicamente, o mesmo que amor.
\end{abstract}

Palavras-chave: Cuidado. Amor. Temporalidade. Presença. Ser.

\begin{abstract}
This article seeks to understand a statement given by Heidegger to Medard Boss, according to which "Sorge" (cure, care) can not be differentiated as opposed to love, as had Binswanger, because it is the name for the constitution ecstatic and temporal of the fundamental trace of presence (Dasein), or, the understanding of being. The article analyzes every moment of this statement and seeks to understand the sense in which care is ontologically the same as love.

Keywords: Care. Love. Temporality. Presence. Being.

Resumen: Este artículo trata de comprender una declaración dada por Heidegger a Medard Boss, según el cual "Sorge" (cura, la atención) no se pueden diferenciar en lugar de amor, como lo había hecho Binswanger, por ser el nombre para la constitución extática-temporal del trazo fundamental de la presencia (Dasein), es decir, la comprensión del ser. El artículo analiza en cada momento de esta declaración y trata de comprender el sentido en que la atención es ontológicamente lo mismo que el amor Palabras-clave: Cuidado. Amor. Temporalidad. Presencia. Ser.
\end{abstract}

\section{Uma Crítica e uma Resposta}

Nos Seminários de Zollikon, certa vez, em diálogo com Medard Boss, Heidegger recorda uma crítica feita a ele por Ludwig Binswanger, de que teria se esquecido de falar de amor. Ele teria falado do cuidado (Sorge) em seu caráter sombrio, teria falado da angústia e do tédio como humores ou disposições fundamentais da existência humana e teria se esquecido do amor. A esta crítica, Heidegger (1994a, p. 237) responde da seguinte maneira:

Contudo Sorge (cura, cuidado), se entendido de maneira correta, isto é, de modo fundamental-ontológico, nunca pode ser diferenciado em contraposição ao amor, mas é o nome para a constituição extáticotemporal do traço fundamental da presença (Dasein), a saber, da compreensão do ser. ${ }^{1}$

O que o presente texto propõe é compreender esta indicação de Heidegger a respeito da Sorge (cura, cuidado). Como compreender aquilo que Heidegger chama de "Sorge" (cura, cuidado)? Em que medida é o mesmo a "cura" e o "amor", ou seja, em que sentido há uma coincidência no ser entre ambos? É fácil, para a nossa representação cotidiana, entender onticamente o amor como cuidado, mas, como entender ontologicamente o "cuidado", a "cura", como amor?

\section{O Horizonte do Entendimento Fundamental- Ontológico}

Entretanto, o que significa esta passagem do ôntico para o ontológico? Denominamos de "ôntico" o que concerne ao ente, ou seja, ao que é, ao sendo. Denominamos de "ontológico" o que concerne ao ser. Esta distinção pressupõe, pois, uma diferença, não entre ente e ente, mas entre ente e ser. Como, porém, esta diferença entre ente e ser é uma diferença de ser e não uma diferença entre entes ou entre aspectos dos entes, não sendo, portanto, uma diferença ôntica, então a denominamos "diferença ontológica”. Nesta colocação, porém, está pressuposto que, se vigora uma diferença, vige também uma referência entre ente e ser. Pois, como poderia haver uma diferença sem referência mútua? Ente e ser se diferenciam à medida que se referenciam um ao outro. Contudo, também esta referência não é ôntica, isto é, uma referência entre ente 
e ente ou entre aspectos do ente, mas uma referência de ser entre ente e ser, portanto, uma referência ontológica. A questão é: como fica essa colocação para quem só tem olhos para o ôntico? Resposta: não fica, supondo-se que haja alguém assim. Mas, há alguém assim? A resposta, neste caso, parece ambígua: por um lado, todos somos de alguma maneira cegos para o ontológico; por outro, todos, por natureza, temos a capacidade de vê-lo. Com efeito, nós já sempre o vimos, mas não nos atinamos para essa visão. Nós já partimos sempre de uma apreensão do ente enquanto ente, e isto quer dizer, do ente no seu ser. Dito de outro modo: nós nos movemos já sempre numa compreensão do ser, embora esta compreensão seja, de início e na maior parte das vezes, não temática, não explícita, não teórica, mas antes "operativa”, que se dá com e no nosso próprio ser, com e no nosso próprio existir, em-sendo, em existindo (Heidegger, 1988, p. 29). Em todo o lidar com o ente nós já sempre o apreendemos como ente simplesmente e, ademais, como ente deste ou daquele ser: o instrumento na sua instrumentalidade, o vivente no vigor da vida, o homem no modo de ser de sua humanidade, etc. Em-sendo, nós mesmos já sempre nos abrimos para o ser, a priori, nós já sempre mantemos uma relação de ser com o que somos e com o que não somos, com o que podemos ser e com o que devemos ser, com o que vamos nos tornando, enfim, com nossas possibilidades e impossibilidades de ser. Esta abertura se dá numa compreensão, que é anterior a toda tematização, que é ela mesma e nela mesma um poder-ser. É a partir desta compreensão, ainda que vaga e mediana, ainda que atemática, que nós podemos dizer "é”, "sou”, "és”, "somos”, conjugando o verbo "ser" nos seus tempos e nos seus modos, abrindo as nossas possibilidades de nos pronunciarmos e de nos comunicarmos, de falarmos das nossas coisas e das nossas causas, etc.

Na indicação acima de Heidegger, somos remetidos ao "ontológico": somos advertidos para o fato de que "Sorge" (cura, cuidado) é entendida corretamente se for assumida de modo fundamental-ontológico, como um traço fundamental que caracteriza o humano enquanto presença, a saber, a compreensão do ser. O ôntico do ente que somos nós mesmos é de tal feitio que é em si mesmo ontológico (Heidegger, 1988, p. 38). O humano enquanto presença (Dasein) se cumpre como e a partir de uma relação com o ser, relação que se cumpre como "compreensão". Ao dizermos "traço fundamental que caracteriza o humano enquanto presença" o fazemos correndo o risco de uma incompreensão, devido à ambiguidade latente nesse dizer. Não se trata do humano enquanto substância (um "certo quê"), nem do humano enquanto sujeito, modo predominante de o humano se dar na época moderna. O humano, aqui, não é sujeito, nem o ser, aqui, não é nenhum objeto. A compreensão do ser por parte do humano também não é nenhum conhecimento objetivo. E, por não ser objetivo, não é nem mesmo subjetivo. Pois só há objeto onde há sujeito e só há sujeito onde há objeto. Sujeito-objeto são dois polos de uma mesma relação funcional. Só vigoram a partir da vigência da funcionalidade. Ora, a presença é um modo de ser epocal do humano que se subtrai a esta vigência da funcionalidade. $\mathrm{O}$ que? Mas, o que experimentamos a todo o momento não é que justamente esta vigência se dá em sua hegemonia incontestável hoje por toda a parte e a todo o momento? Na vigência da funcionalidade tudo já não se tornou sistema? Talvez sim. E na vigência do sistema, tudo não já se tornou insumo e recurso e não é a partir daí que se organiza a "sociedade da produção", inclusive sua última concreção, a "sociedade do conhecimento"? Então, o que é a presença? Neste contexto, talvez uma possibilidade de ser do humano que não há, um nada. Somos e não somos presença. Ou melhor: em não sendo presença, podemos ser presença. Mas este poder-ser pressupõe a necessidade de nos subtrairmos da hegemonia da funcionalidade, isto é, da objetividade e da subjetividade, do sistema e da vivência. Este subtrair, no entanto, não é nenhuma fuga ôntica, mas é, antes de tudo, um adentrar mais profundamente, só que esta "introdução" é de cunho ontológico. Supõe a intenção de pensarmos o sentido de ser que vigora na hegemonia da funcionalidade, de seguirmos o que aí se retrai, o que se encobre e se vela, o que se resguarda e se protege, como um “nada” (Heidegger, 1999, p. 57-63).

Portanto, falar do humano enquanto presença e do traço fundamental do cuidado, não é descrever o humano enquanto algo já constituído, enquanto um determinado quê aí ocorrente, com determinadas propriedades características, objetivamente dadas. Nem é mesmo falar do humano enquanto sujeito que se autoconstitui em seus relacionamentos com os objetos e o mundo objetivo, com o outro enquanto objeto ou mesmo com o outro enquanto outro sujeito no mundo das relações intersubjetivas; nem consigo enquanto objeto, nem mesmo consigo enquanto sujeito, pondo-nos na perspectiva de um mundo intrasubjetivo. É que todo objetivo e todo o subjetivo, mesmo o inter e o intrasubjetivo, tanto a perspectiva da racionalidade e suas operações, quanto da animalidade e de suas vivências, já se encontram no lance da compreensão de ser dominante e hegemônica hoje, que é o da funcionalidade.

Falar do humano enquanto presença, porém, é outro lance. Isto é, significa abrir outro horizonte de compreensão, por conseguinte, de poder-ser. É um aceno ao futuro, portanto (Heidegger, 1994b, p. 294). Contudo, não se trata de entender o futuro como prolongamento do passado e do presente, mas como porvir, um porvir a partir donde emerge a possibilidade de uma passagem, que reponha o humano numa relação originária com o ser. Contudo, mais uma vez, não se trata de passar de algo real a outro algo real, mas da passagem de um poder-ser a outro poder-ser, de uma passagem que é, na verdade, um salto, um salto de liberdade que, abismando-se no nada, funda outro modo de ser para o humano, um modo de ser que se chama presença por possibilitar ao humano ser o 
aí do ser, ou seja, que se rege na proximidade do ser, do ser não como funcionalidade, mas do ser como eventoapropriador (Ereignis).

Se essa for a questão, então o humano que hoje vigora não é tanto presença, mas ausência (Heidegger, 1994b, 323). O que hoje celebramos como ser não é tanto ser, mas nada; o que hoje consideramos um nada, não é tanto um nada, mas ser numa plenitude ainda não pressentida. Esta passagem é, portanto, uma guinada (Kehre) no ser e no humano. E a crise de nosso tempo pode guardar em si a prenhez de uma decisão, que versa sobre esta passagem, ou seja, se ela acontece ou não, quer dizer, se aquela guinada se consuma ou não. Ou então, a decisão que versa sobre o fato de se esta decisão mesma acontece ou se ela simplesmente não acontece e o homem e o ser sigam vigorando como vigoram (ou como não vigoram) na hegemonia da funcionalidade. Em todo o caso, pensar em face a essa decisão que é um poder-ser, significa, sempre renunciar a toda futurologia e cálculo sobre o futuro e a aguardar, na vigilância, o inesperado de uma outra parusia do ser e, por conseguinte, de uma outra essencialização do humano. A questão é: se da crise que abala os fundamentos mesmos de uma história que vigora há cerca de dois milênios e meio, pode irromper uma outra regência do ser e uma outra vigência do humano. Neste contexto, se o pensamento também encontra um caminho de passagem para outro início em diálogo com as fontes do primeiro início, de onde vivem as possibilidades da metafísica, cuja última ressonância é o domínio absoluto da tecnociência e o controle do real pelo virtual.

À luz desta situação epocal, há que se ler de modo diverso o sentido de uma ontologia-fundamental. Para começar, ontologia não é, aqui, uma disciplina que estuda o ente, mas sim um pensar que busca, pergunta, questiona, investiga o sentido do ser. Enquanto tal, ela fundamenta e supera, ao mesmo tempo, toda ontologia (Heidegger, 1994b, p. 305). O que está em jogo aqui é, na verdade, uma transformação no próprio perguntar do pensamento: a passagem do questionamento que pergunta pelo ser do ente (o que é o ente enquanto ente, isto é, o que é o ente no tocante ao ser?), que visa o ser como entidade, para o questionamento que pergunta pela verdade do ser mesmo, de seu desencobrimento e encobrimento, ou melhor, de seu abrir-se e clarear-se e de seu resguardar-se e ocultarse. Isto significa: estar atento à verdade do ser, ao modo como o ser, dando-se, se retrai; presenteando-se, se subtrai; destinando-se, se resguarda. Pensar é, neste sentido, deixar-se atrair pela força de tração do retraimento do mistério do ser nas destinações de nosso tempo. É estar atento ao nada na vigência do ser, ou seja, à ausência na presença e à presença na ausência, seguindo, nos cursos, percursos e discursos da linguagem, a dinâmica do tempo. Pensar é, pois, fundar, no humano, o “medium” para o dar-se da verdade do ser. É, por conseguinte, cofundar o humano como presença: ser o aí-do-ser. Neste sentido, a ontologia fundamental é uma arrancada para a passagem, um embalar-se para o salto, um primeiro movimento em favor da fundação da verdade do ser no humano como presença. Isso comporta uma transformação do humano de senhor do ente em pastor do ser:

O homem foi 'lançado' pelo próprio Ser na Verdade do Ser, a fim de que, ec-sistindo nesse lançamento, guarde a Verdade do Ser; a fim de que, na luz do Ser, o ente apareça como o ente que é. Se e como o ente aparece, se e como Deus e os deuses, a História e a natureza ingressam, se apresentam e se ausentam da clareira do Ser, isso não é o homem quem decide. $\mathrm{O}$ advento do ente repousa no destino do Ser. Para o homem, a questão é, se ele encontra o que é 'destinado' à sua Essência, correspondente ao destino do Ser. Pois é de acordo com esse destino, que, como ec-sistente, ele tem de guardar a Verdade do Ser. O homem é o pastor do Ser. É somente nessa direção que pensa Ser e Tempo, ao fazer, 'na Cura', a experiência da existência ec-stática (Heidegger, 1967, p. 50s).

Partindo, pois, destas indicações de Heidegger sobre a "Sorge" (cura, cuidado) em seu sentido ontológico, tentemos aprofundar a sua compreensão e ver o que ela tem a ver com o amor.

\section{Presença e Ausência}

A primeira indicação diz: "Sorge" (cura, cuidado) é o nome para a constituição extático-temporal do traço fundamental da presença (Dasein), a saber, da compreensão do ser. Como entender esta indicação?

Em primeiro lugar, o que quer dizer presença (Dasein)? Em sentido usual na língua alemã Dasein significa estar aí. Heidegger usa a palavra francesa "présence" (presença), aludindo ao significado usual de Dasein. Aqui convém apresentar a citação na língua alemã, seguida da sua tradução em língua portuguesa, para que apreendamos este uso da palavra.

No significado costumeiro, porém, quer dizer, por exemplo: a cadeira “está aí”; o tio “está aí”, ele chegou e está presente; daí: presença (Heidegger, 1994b, p. 300).

No significado usual, pois, o verbo dasein quer dizer "estar aî": presença. Em grego seria parousia. O nome parousia significa presença, aparecimento, vinda. A tradução para o latim é: adventus. Parousia remete ao verbo pareimi, estar presente, ter vindo. O que está aí é pensado, pois, como o que adveio ou sobreveio. Presença é a vigência do que advém e sobrevém. Perdendo-se de

\footnotetext{
2 In der gewöhnlichen Bedeutung jedoch meint es z.B.: der Stuhl "ist da"; der Onkel "ist da”, ist angekommen und anwesend; daher présence. Grifos de Heidegger.
} 
vista esta dinâmica temporal, porém, a presença passa a ser entendida como simples "ousia": a presença ou o que está presente, ou seja, o que está aí. Caso se entenda a presença do presente como o repousar em si mesmo, como autossubsistência ou autoconsistência, visando o ser em si de alguma coisa, então ousia se traduz em latim para substantia (substância). Entretanto, na história da metafísica, a compreensão do ser vai se esvaziando cada vez mais: de vigência do que advém a simples presença e da simples presença a substância e da substância ao mero ocorrer aí de algo, de uma res (coisa), de certo "quê" (aliquid). Na modernidade, o "quê" passa a ser interpretado como o que é apresentado e representado por e para um sujeito, ou seja, por um ente que é fundamento ou suporte (subjectum) de toda apresentação e representação dada no conhecimento, o qual passa a ser compreendido em sua função objetivante, e cuja constituição se dá como autopresença ou como presença de si a si mesmo (a "mens", o "ego cogito", a "res cogitans"). A presença por excelência passa a ser esta substância que é autopresente e que se apresenta e representa todo o ente no projeto de domínio calculador de todo o ente, pela ciência e pela técnica. A partir daí todo o ente, objetivo (simplesmente presente) ou subjetivo (autopresente), se equaciona no horizonte da funcionalidade do "poder", ou melhor, da inessência do poder, que agencia o domínio, que tudo domina, explora e controla. O ser do ente, ou seja, a presença do presente passa a ser compreendido no horizonte da funcionalidade, isto é, como recurso, insumo, elemento de um processamento infinito de produção. Em tudo isso, porém, a presença é pensada a partir da compreensão do ser como simples ocorrência, isto é, na perspectiva da instrumentalidade ou da disponibilidade para a produção. Tudo se nivela na impessoalidade funcional. O homem mesmo se torna um "que", um elemento, recurso, mesmo que fundamental, dentro da vigência desta funcionalidade técnico-científica, a serviço da produção.

Contudo, a partir da ontologia fundamental, "presença” (Dasein) nomeia justamente a apreensão e compreensão de um poder-ser do homem, do humano e de sua humanidade, que se subtrai ao horizonte da simples ocorrência, quer como substancialidade, quer como subjetividade e objetividade, quer ainda como recurso da funcionalidade produtiva. Presença nomeia, então, não simplesmente um "quê", mas um "quem”. Ela responde não à pergunta: "o que somos nós?”. Ela corresponde ao questionamento "quem somos nós?” (Heidegger, 1994b, p. 48-54). Presença não é algo, mas alguém. Seria, porém, um equívoco logo empurrar a presença para dentro do horizonte da "pessoa” (Heidegger, 1988, p. 84-85). Com efeito, a pessoa veio sendo interpretada, ao longo da história, ou como substância ou como sujeito e hoje se encontra absorvida na impessoalidade funcional da técnica e da sociedade de produção, inclusive em seus aspectos "vivenciais". A presença como "ser-quem" e não como "ser- que”, portanto, haure o seu vigor do porvir, como fundamento para o homem porvindouro. Ela é um apelo de ser que nos alcança, ou seja, que alcança a nós, humanos deste tempo, na passagem. Alcançar uma compreensão do cuidado requer, portanto, a capacidade de nos mantermos no sentido de ser (horizonte de compreensibilidade) que nos advém do "ser-quem", subtraindo-nos, assim, do sentido de ser dominante do "ser-que".

A partir desta perspectiva, o que nós temos comumente como presença (Dasein, ousia), a saber, a mera presença, a ocorrência no horizonte do "ser-que", tanto como substancialidade quanto como objetividade-subjetividade, ou ainda quanto como recurso da funcionalidade, passa a ser chamado de ausência (Wegsein, apousia). Arrebatado, isto é, endoidecido e apaixonado pela mobilização total do produzir e do dominar, encantado pelos dispositivos e pelas disponibilizações da operacionalidade funcional da técnica, em toda a parte e a todo o momento ocupado e preocupado com o ente, ao homem permanece velado, oculto, desconhecido, o mistério do ser. Ele, epocalmente, "não está nem aí” para o mistério de ser. Este fechamento e encobrimento que vigora como esquecimento, melhor, como esquecimento do esquecimento, só pode ter o ser como nada, só pode ter o pensar que medita o sentido do ser como delírio. Esta situação não é superada ali onde se condena a racionalidade com sua unilateralidade e se procura refúgio nas "vivências" (Heidegger, 1994b, p. 131). Por isso, o pósmoderno é ainda, neste sentido, um prolongamento do moderno, da ausência que se consuma na modernidade, portanto, não é propriamente uma passagem, mas uma aparência de passagem. Uma passagem só se cumpre na presença e como presença.

Presença é um modo de ser, no qual o aí é, tomando-se o verbo ser, por assim dizer, como ativo-transitivo (Heidegger, 1994b, p. 296). Ser o aí é, por assim dizer, fundar o aí, deixar e fazer viger o aí, a saber, o aí para o ser e do ser. Presença é "estar aî” para o mistério do ser. É ser o aí, ou seja, a abertura que deixa ser o ser em sua proximidade. Cuidado é o ser (o viger) do aí. O homem, fundado na presença, deixa de ser o senhor do ente, para se tornar o cuidador do ser. Somente cuidando do ser é que o homem deixa ser o ente como ente. Do contrário, no esquecimento do ser, o ente só vigora em sua inessência, em sua niilidade (niilismo). Contudo, se a presença vigora como um "ser-quem" e não como um “ser-que”, então, também o "ser” e o "cuidar” só poderão ser apreendidos e compreendidos em seu sentido a partir do "ser-quem".

Entretanto, poder-se-ia perguntar: qual a necessidade da transformação do humano, aqui evocada, de senhor do ente em cuidador do ser? Resposta: o homem precisa se transformar para poder-ser si-mesmo. É no horizonte do poder-ser-si-mesmo que se inscreve a necessidade de o humano e sua humanidade se fundar no fundo e no abismo (sem-fundo) da presença. 


\section{Os Momentos Estruturais do Cuidado: Existencia- lidade, Facticidade e Decadência}

Voltamos, agora, à indicação dada por Heidegger a respeito de como compreender o cuidado. "Sorge" (cura, cuidado) é o nome para a constituição extático-temporal do traço fundamental da presença (Dasein), a saber, da compreensão do ser.

O cuidado é indicado como "traço fundamental" da presença. Não se há de entender o cuidado, porém, como uma característica ou uma propriedade ôntica de um ente que ocorre aí ("presença" como ocorrência). O traço resulta de um traçar. $\mathrm{O}$ traçar, contudo, se cumpre num imaginar. O humano como presença é uma imaginação (Heidegger, 1994b, p. 312). Contudo, essa imaginação não é nem empírica nem transcendental. É, antes, existencialontológica. Este imaginar tem o sentido de trazer à luz o que vigora como poder-ser. Significa intuir no porvir outra possibilidade de configuração do humano e de o humano ser o que ele é, ou seja, configurador do mundo. Trata-se, portanto, de criar, a partir do poder-ser, outra forma de essencializar-se do humano, na qual a humanidade do homem não se encontre fechada, mas aberta para o mistério de ser. Imaginação tem o sentido, aqui, de projeção da fundação da presença em seu poder-ser fundamental, como clareira do ser.

$\mathrm{Na}$ ontologia fundamental, o cuidado aparece como uma totalidade estrutural (Heidegger, 1988, p. 255). Estrutural é aquela totalidade em que o todo se encontra todo em cada um de seus momentos. Isso quer dizer: totalidade não é, aqui, soma de partes, pois a presença não é nenhuma ocorrência (coisa ou "substância"); também não é sistema, pois a presença não é um ente que ocorre a modo do ser funcional (mecânico ou orgânico, causaleficiente ou causal-teleológico). Estrutural é uma totalidade existencial, isto é, uma totalidade que tem o modo de ser da liberdade. Isto quer dizer que as estruturas do cuidado são estruturações da liberdade. Somente a partir do sentido de ser (horizonte de compreensibilidade) do ser-quem e da liberdade (ser-livre) é que pode acontecer a compreensão do poder-ser da presença e, por conseguinte, do cuidado.

A estrutura do cuidado reúne três momentos: existencialidade, facticidade e de-cadência (Heidegger, 1988, p. 255).

Existencialidade é o caráter de ser da existência. A palavra existência, aqui, não tem o sentido habitual de ocorrência efetiva de alguma coisa, nem mesmo o sentido tradicional filosófico. Em sentido tradicional a palavra existência significa o "que" do ser: que o ente é (que-ser) e que ele é como ele é (como-ser). Esta se conjuga com a essência ou quididade: "o que" o ente é (o queser). Enquanto a essência é entendida como possibilidade (potência), a existência nomeia a realização efetiva daquela possibilidade, o ser real do ente (ato, realidade como efetividade). Existência, porém, no contexto da ontologia fundamental significa a essência (no sentido verbal de viger, de conceder ou propiciar vigência) da presença (Dasein), do ser-quem. Se a existência é a essência (o que deixa e faz viger) da presença; a cura ou cuidado (Sorge) é a essência da existência; e a temporalidade é o sentido de ser da cura (Sorge); então a existência é (vige como) temporalidade. A existência é, portanto, essencialmente extática. "Ex-sistere" significa "estar fora de si", "pôr-se de pé no fora", isto é, ser exposto ao ente como ente, ou seja, estar fora na abertura do ser. Existir é, neste sentido, estar inserido na verdade do ser; é insistir nela; é nela estar arraigado.

A partir deste caráter extático é que se determina o que é o ente em questão (a presença): ele não é um que, mas um quem. Enquanto tal, ele não é uma coisa que ocorre aí, simplesmente dada; nem uma coisa de uso, um instrumento, cuja serventia se dê para isso ou para aquilo, mas ele é por mor de si mesmo (worumwillen) (Heidegger, 1988, p. 256). Esta expressão "por mor de" significa na linguagem habitual "por causa de". Em sua origem, porém, tem o sentido de "por amor de". A presença, enquanto existência, é não por amor de outra coisa (não é "um meio para um fim" - usando-se o modo de dizer de Kant), mas é por amor de si mesma (é "um fim em si mesma"). Isso porque, na presença enquanto existência, ou seja, enquanto um ente da liberdade, o que está em causa ou em jogo é, cada vez e sempre, em toda decisão, o seu ser, o seu poder-ser si-mesmo. Existir é, neste sentido, ser livre para o poder-ser mais próprio. Enquanto tal, ou seja, enquanto ser-para-o-poder-ser-mais-próprio, existir significa já sempre estar indo adiante de si mesmo, antecipar-se, preceder-se a si mesmo (sich vorweg sein). Existir é, pois, ultrapassar-se, transcender-se. Só que este transcender-se não é ultrapassar-se na direção do que não se é, mas sim, ultrapassar-se na direção do próprio ser, ou melhor, na direção do poder-ser mais próprio, ou seja, daquele poder-ser em que a presença pode ser mais propriamente o que, melhor, quem ela é. Existir é, pois, estar sob a lei da liberdade, que diz: "torna-te o que tu és". Isto significa: torna-te quem tu és, melhor ainda, tornate quem tu podes ser.

O si-mesmo, aqui, não é a coincidência do eu consigo próprio, a coincidência entre o representador e o representado, a autoconsciência ou autopresença da mente. O si-mesmo é a regência do próprio. É o acontecer pelo qual a presença vem a si e para junto de si (Heidegger, 1994b, p. 319). Somente à medida que a presença vem a si e junto de si é que ela pode propriamente assumir o ser para os outros. É a partir do si-mesmo que o eu, tu, nós encontram seu modo apropriado de ser. O vir para si e o ser junto de si da presença, porém, não se dá como reflexão da consciência, como autoconsciência do eu. A "retrorrelação" expressa no "vir-a-si" e no "ser-junto-de-si" não pode ser compreendida a partir do horizonte da consciência e de sua reflexão, mas é um acontecer da presença a partir da regência do próprio. O si-mesmo não é algo 
já dado, a modo de ocorrência. O si-mesmo é o dom de uma apropriação e a apropriação de um dom. Apropriarse, aqui, porém, não é apossar-se do que já está aí, como algo simplesmente dado ou como um recurso ou coisa de uso. Apropriar-se significa tornar-se apto no poder-ser mais próprio. Querer possuir, dominar, assegurar-se é um modo impróprio de se apropriar do vigor do próprio (da "propriedade" da existência). Este querer só demonstra a inaptidão para o próprio. Mas, o que torna a presença apta à regência do próprio, à propriedade da existência? Resposta: a abnegação, a renúncia. A abnegação não é a mera negação de si. Mas a negação do modo impróprio de querer apropriar-se de si: ou seja, do querer possuirse sem conquistar-se, sem conquistar a aptidão para ser, a capacidade de poder-ser. A negação da abnegação não é mera negatividade.

A renúncia não tira. A renúncia dá. Dá a força inesgotável da simplicidade (Heidegger, 1977, p. 48).

Portanto, a renúncia não é perda. No não da renúncia vigora o poder-ser do sim à verdade do ser. A renúncia anuncia o que se vela e se oculta (Heidegger, 2003, p. 129). Ela assinala o retraimento do mistério do ser, o outro do ente. A renúncia não tira. A renúncia dá. Dá a força inesgotável da identidade de si sob a regência do próprio. Por isso, a aptidão do poder-ser se consuma como dedicação, na pertença ao ser. Ela é crescimento e maturação de si a partir do ser.

A aptidão do poder-ser acontece como doação à verdade do ser. E isso significa: é recepção à regência do ser. Esta, porém, a regência do ser, consiste em provocar cada ente para o seu próprio. Ele concede a vigência do próprio a cada e a todo o ente (Heidegger, 1967, p. 28). Dito de outro modo: é o ser que deixa e faz ser o ente no seu próprio, é ele que leva cada ente à sua propriedade. Por isso a aptidão do poder-ser, pelo qual a presença se torna si mesma, consiste em receber do ser o vigor de ser o próprio de si e em comunicar adiante este vigor. Somente no pertencimento ao ser é que a presença alcança constância e consistência de ser-si-mesma e somente sendo propriamente si mesma é que ela pode dizer propriamente eu, tu, nós. Existência não é, pois, outra coisa do que a insistência, a consistência e a constância da presença na verdade do ser.

Facticidade é o caráter de ser do fato de a presença já existir, mais precisamente, de já ser-no-mundo (Heidegger, 1989, p. 71-73). Neste sentido, a facticidade é ontologicamente diferente da factualidade do ente simplesmente dado ao modo da ocorrência ou do ente à mão que se dá ao modo da instrumentalidade. Embora sejam reais, estes não existem, no sentido do uso aqui dado à palavra "existência", como um existencial.. Estes não têm o modo de ser-no-mundo, mas apenas vêm ao encontro da presença como entes intramundanos. Enquanto já-serem (o mundo) a facticidade é o a priori da existência, a sua autodatidade, o já ser si-mesmo, do si-mesmo, para simesmo (autorrelação). Entretanto, o si-mesmo é si-mesmo para si-mesmo, concretamente, em sendo, em existindo, e isto quer dizer: entregue à própria responsabilidade de assumir este fato de já ser. A presença existe em concreto, tendo que ser si-mesma, submetida à necessidade da liberdade. Em concreto quer dizer: como cada-vez-minha em sua singularidade e na respectividade de cada vez, ou seja, inserida na finitude de cada situação. A facticidade é o fato de que, sendo, a presença já está lançada no aí e já se abriu como disposição, compreensão e linguagem; é o fato de que, sendo, ela já se precedeu a si mesma, ou seja, já está a caminho de si-mesma e já se lançou para o ser como um poder-ser; o fato de que, sendo, ela já se achou a si-mesma em alguma disposição ou humor, já abriu o mundo como uma estrutura remissiva de significâncias e já articulou e recolheu a sua compreensibilidade na linguagem. A facticidade é o fato de a presença não poder retroceder ao fato de já-ser-em-o-mundo, ao fato de já ser e de ter que, sempre de novo, ser. A presença, com efeito, não pode nunca estar diante de sua existência. Ela só pode ser a partir da existência, como existência e em vista da existência. Por isso, a presença não pode nunca absolutamente dominar a existência. A facticidade é o fato ambivalente de a presença não ser fundamento de si e, ao mesmo tempo, ter que ser fundamento de si mesma. O fato de não ser fundamento de si mesma, ou seja, de já estar lançada no aí, na abertura da verdade do ser, mostra sua niilidade. $\mathrm{O}$ fato de ser fundamento de si mesma, ou seja, o fato de ter que ser si-mesma, assumindo o seu próprio poder-ser, a cada vez, mostra sua liberdade. O fato de existir, com efeito, a presença assume sempre de novo e a cada vez, na solidão de sua singularidade e na finitude de sua mortalidade, na comunhão do ser-comos-outros, como cuidado (Sorge), exercendo-o concretamente na ocupação (Besorgen) com as coisas intramundanas e na preocupação (Fürsorge) com os outros. E este exercício se dá concretamente nos lances pelos quais ela assume o seu poder-ser, que é, também e de modo igualmente originário, um poder-ser-no-mundo e um poderser-com-o-outro. A presença é seu fundamento em existindo, ou seja, em podendo ser, ou seja, em assumindo ou não o poder ser si-mesmo, a regência da propriedade. Por isso, a presença pode cumprir-se entrando nesta regência ou desviando-se dela, abrindo-se ou fechando-se para a verdade do ser.

A decadência constitui a inessência da existência. Entretanto, enquanto inessência, ela pertence à essência como uma sua possibilidade, na verdade, como aquela possibilidade que de início e na maior parte das vezes já se realizou, na facticidade da existência. Ela é o avesso da existência. Só que este avesso é justamente o modo mais comum dela, a existência, se dar (Heidegger, 1989, p. 144-147). Por ela, o homem diz "eu sou”, mas em verdade não é, isto é, não vigora na propriedade do ser-simesmo. Por ela, cada um é, antes de tudo, "os outros": o "a gente" que, na verdade, é "todo o mundo", que, em última instância, é "ninguém”. Por ela, a existência é arrebatada pelo mundo das coisas de que se ocupa, se 
move em relacionamentos impessoais e se dissipa no falatório, na curiosidade e na ambiguidade da publicidade. Decadência é desarraigamento, um desarraigamento fundado no fato de já ser-junto ao ente. Mas é, acima de tudo, uma cadência: uma mobilidade e movimentação do existir, cuja característica é a precipitação para o nada negativo, ou seja, o nada aniquilante. Não que com ela o homem fosse destruído. Mais do que a destruição do homem, ela é a aniquilação do fundo ontológico do poder-ser pelo qual o homem pode construir o seu modo de ser, isto é, se constituir como humano em sua humanidade. Nela, o homem pode permanecer, mas permanece inumano. A existência continua, mas em simulacros. Radicalmente acomodada em sua movimentação, promove a agitação frenética do fazer, do agir, do empreender, escolhendo o imediatamente útil como critério último de valor de tudo e de todos. A sua niilidade, portanto, não é a niilidade da não ocorrência, mas é uma niilidade que se dissimula na efetividade, na proximidade da vida, na exaltação do "concreto". Na decadência, a existência foge de si mesma, se aliena, se fecha, se aprisiona, gira de modo vazio em torno de si mesma, como em um vórtice. Pela decadência a existência desliza em defasagens: do ser ao ente; do si-mesmo ao mundo; do mundo ao intramundano; do que está à mão no uso como coisa ao simplesmente dado; do simplesmente dado como objeto ao recurso. Uma mobilidade de precipitação, portanto, que vai da vigência à mera ocorrência, do recolhimento no uno à dispersão na multiplicidade, da plenitude e prenhez ao vazio e esterilidade, da originariedade criativa e criatividade originária à estereotipia, da abertura ao fechamento, do desencobrimento ao encobrimento dissimulador, da verdade ao falseamento.

\section{Cuidado como Constituição Extático-Temporal da Presença}

Mais uma vez, retomemos a indicação inicial que nos guia nesta reflexão: "Sorge" (cura, cuidado) é o nome para a constituição extático-temporal do traço fundamental da presença (Dasein), a saber, da compreensão do ser. Acabamos de ver como esta constituição se articula em três momentos estruturais: a existencialidade, a facticidade e a decadência. Agora tentemos entender como esta constituição se denomina "extático-temporal".

A totalidade estrutural da cura ou do cuidado (Sorge), que se articula em seus momentos (existencialidade, facticidade e decadência) não é uma moldura rígida na qual a presença se realiza, nem é um arcabouço estático a partir do qual o homem constrói sua humanidade (Heidegger, 1988, p. 255-256). A totalidade estrutural da cura ou do cuidado (Sorge) é, essencialmente, temporalidade. Tratase, aqui, não da intratemporalidade do ente intramundano que ocorre "no tempo". Também não se trata de uma temporalidade psíquica, vivenciada de modo imanente por um sujeito em sua consciência. A presença não ocorre "no tempo" como se fosse algo intramundano. O fato de ela se interpretar a si mesma como tal é apenas uma sua possibilidade, no esquecimento de si mesma junto às coisas com que ela lida. A presença também não é pura e simplesmente a consciência na qual e para a qual o tempo ocorre. Tanto o tempo objetivo (físico), quanto o tempo subjetivo (psíquico) são modos defasados de se entender a temporalidade existencial. A presença só tem tempo e vivencia tempo por já ser tempo. A temporalidade não é algo que ela tem, mas algo que ela é. Por exemplo, ela apenas conta o tempo no calendário por que precisa contar com o tempo em sua ocupação. Mas ela só conta com o tempo em sua ocupação porque o seu tempo está contado, isto é, porque ela é mortal. Temporalidade implica, radicalmente, finitude.

A temporalidade, porém, não é, no sentido do ocorrer ou do estar à mão. Ela somente é no sentido do vigorar em temporalizações: futuro, presente e passado. As temporalizações não se sucedem uma à outra. O futuro não vem depois do passado e o passado não vem antes do presente. A cada instante, a presença é o seu porvir, o seu ter-sido e o seu presente. A unidade dessas temporalizações é a temporalidade. A temporalidade perfaz radicalmente o ser da presença, tornando-a extática, isto é, fora de si. As temporalizações são "êxtases", isto é, mobilizações que empurram a presença, constituindo-a como "fora de si", como existente (Heidegger, 1989, p. 123). Estes "empurrões” abrem a presença em seu aí e a torna a aberta do ser, o espaço de liberdade, onde emerge a claridade do ser. A temporalidade extática libera e ilumina, pois, o aí do ser, a presença em sua existência. Por ser temporalmente extática é que a presença é cura, cuidado (Sorge). A temporalidade é o fundamento existencial da cura.

O modo mais imediato de cuidado se dá como ocupação (Besorgen). As ocupações com os entes intramundanos, de fato, preenchem os dias do homem. A cada dia toca o seu cuidado. O cotidiano é, neste sentido, o tempo das ocupações, da lida. É no ordinário do cotidiano que a presença tem a experiência do extraordinário que é existir. É na familiaridade do ser-no-mundo a partir das ocupações cotidianas que se cumpre a sua estranha forma de ser: a estranheza de existir. Desta estranheza normalmente ela já fugiu e, movida pela angústia latente desta estranheza, que traz entranhada o saber de sua facticidade e de sua mortalidade, ela já se lançou em mil cuidados e já se dispersou em fazeres e afazeres desarraigados; já se entregou também à ditadura do impessoal e abriu mão do poder-ser si-mesma, delegando "aos outros"o que ela deve ser, dispersando-se no falatório, na curiosidade e na ambiguidade da (in-) compreensão habitual e corriqueira. Esta fuga se torna precipitação e, em seu desarraigamento, tende a se acelerar cada vez mais, entregando-se cada vez mais à velocidade das próprias atividades e empreendimentos, bem como das próprias diversões e entretenimentos. 
Existindo, a presença é junto do ente de que se ocupa, junto do "mundo" das coisas, isto é, no mundo das ocupações, que é o mundo circundante. Existir é empenharse no mundo. É ter a ver com as coisas e se interessar por elas. Este ter a ver, porém, se dá numa visão que é uma circunvisão: uma visão que administra as possibilidades de ocupação com as coisas ao redor. Isto significa apreender e reter as referências que as coisas guardam umas com as outras enquanto coisas que se dão num nexo instrumental e numa conjuntura do uso, que, por sua vez, estão em vista da presença mesma e de sua existência. Este apreender e reter de possibilidades de uso constitui o empenho contínuo da presença de atualizar o que está à mão. Por isso, o tempo da ocupação é, fundamentalmente, o tempo atual, o presente (Heidegger, 1989, p. 151-157).

Com a abertura do aí pela temporalidade abre-se também o mundo da ocupação. Este mundo é o horizonte de todos os horizontes dos afazeres do cotidiano. O mundo não é simplesmente dado como ocorrência, nem é à mão como instrumental. O mundo é o horizonte que se abre a partir do "fora de si" da presença. É esta abertura horizontal-extática do mundo que possibilita a descoberta das possibilidades de uso das coisas. Entretanto, a presença atualiza estas possibilidades tendo em vista a sua própria existência, ou seja, cuidando de seu poderser, que é também, de modo igualmente originário, um poder-ser com os outros. É junto das ocupações, de fato, que, de início e na maior parte das vezes, nós nos encontramos com os outros. É a partir delas que se articula a convivência cotidiana. Na impessoalidade desta convivência, cada um é aquilo que ele faz no mundo aberto da publicidade, do "todo o mundo". Entretanto, o ocupar-se com as coisas, que é momento constitutivo e imprescindível da existência enquanto cura, pode levar em conta o poder-ser mais próprio e ser assumido em vista deste poder-ser ou pode se perder na dispersão das muitas atividades, alimentando a fuga de si mesmo. O sentido positivo do fazer é a dedicação (Rombach, 1977, p. 44; 52). Pela dedicação o homem penetra nas possibilidades das coisas e as deixa e faz ser, ou seja, as faz emergir no seu próprio. No emergir das coisas como obra de sua dedicação, o homem também emerge como presença em sua existência. Esta penetração das possibilidades e este deixar-ser que faz emergir as coisas em sua propriedade é a forma de compreensão originária das coisas. Esta compreensão, porém, é em-sendo, ou seja, é operativa. Ela acontece no pôr-em-outra a coisa em sua possibilidade mais própria. Esta compreensão é arte. Ela é um saber, que é poder, mas um poder, que é deixar-ser, que fazer emergir a coisa na sua propriedade, como coisa. Trata-se de uma doação positiva, por ser originária e criativa, às coisas. É uma forma positiva de êxtase pois nela o homem se esquece de si e se doa ao mundo, sem contudo, perder-se a si mesmo, ou seja, sem perder o seu próprio poder-ser si-mesmo. É fazendo, deste modo, coisas, que o homem se perfaz a si mesmo. É expondo-se ao mundo neste cui- dado positivo, que é doação, entrega, esquecimento de si, criação diligente e afetiva, que o homem originariamente se edifica a si mesmo. Tal modo de ser pode ser visto, por exemplo, no brincar da criança. O brincar é o modo primordial pelo qual o humano aprende a seriedade da dedicação criativa e criadora ao mundo das coisas.

A defasagem, porém, desta dedicação é o fazer como entrega desarraigada e dispersa ao mundo das coisas, do uso e abuso, da instrumentalidade e instrumentalização. Na decadência, a atualização se torna inconsistente. Ela é o apelo do imediato, a cobiça do sempre novo, o abandono do poder-ser si-mesmo em favor da realização das coisas como efetivação que se supera sempre de novo a si mesma num horizonte infinito. Em sua agitação, este fazer não guarda o modo de ser da finitude, ou seja, da autoresponsabilização da liberdade. Ela dispara em um agenciamento sem fim, esquecendo-se da mortalidade e da niilidade da própria facticidade. Este disparo, que é também um disparate, atropela as coisas e não as deixa ser no seu próprio. A coisa deixa de ser coisa, para ser apenas objeto de domínio e exploração, recurso para uma infinita demonstração de um poder que não é propriamente poder, pois se esvaziou da autoridade, cujo sentido consiste em deixar e fazer crescer o vigor de ser de todas as coisas. Deste modo, a presença fica sem amparo, sem apoio, sem abrigo e guarida em seu ser-no-mundo. O seu habitar torna, assim, o mundo imundo (inóspito). A existência se fecha à sua pertença ao céu e à terra, à verdade do ser.

O homem tende a se deixar tomar pelo mundo, como o contexto ou a tessitura de relações, referências e remissões em que ele se empenha. Tomado pelo mundo, ele se deixa absorver pelo habitual e familiar. A familiaridade do mundo acaba reprimindo e desviando a atenção da estranheza da facticidade de existir, que pertence essencialmente à presença. Esta familiaridade é perturbada, porém, de maneira imprópria, pelo temor (Heidegger, 1988, p. 195-197). O temor ameaça a presença a partir de um determinado ente em concreto. Essa ameaça atinge e perturba a presença, que se interpreta a si mesma a partir do "mundo", isto é, a partir dos entes intramundanos e até mesmo como um ente intramundano. $\mathrm{O}$ temor perturba $\mathrm{e}$ confunde o atualizar das possibilidades de uso, em que a presença cotidianamente se move. Entretanto, o temor não abala a familiaridade do mundo e o ser-tomado-pelo mundo por parte da presença. O humor que torna possível a retirada da presença deste arrebatamento na familiaridade do mundo é a angústia. A angústia é um despertar do esquecimento do si-mesmo nos empenhos cotidianos que se insere na familiaridade do mundo. É um despertar, porém, por ser um estranhamento.

A angústia traz de volta a presença de sua fuga no mundo e a põe em face ao seu já-ser-em, ao seu já-serlançado, ou seja, de sua facticidade, desvelando a estranheza da familiaridade cotidiana do ser-no-mundo. Pela angústia, o mundo enquanto estrutura remissiva de sig- 
nificâncias se torna insignificante. A angústia revela o nada do mundo (Heidegger, 1999, p. 60). É com o nada do mundo, isto é, com sua estranheza, que a angústia se angustia. Com isso, também, a presença é remetida de volta à facticidade de seu existir, ou seja, à niilidade de seu fundamento. Mas, esta niilidade que a angústia desvela não é a niilidade de um nada negativo ou simplesmente privativo. Trata-se, antes, de uma niilidade positiva e criativa, pois ela também revela que a presença em seu poder-ser e que ela está entregue à responsabilidade por dar sentido a esse poder-ser. Ela mobiliza a presença para assumir a sua responsabilidade de ser, para repetir, isto é, ir buscar de novo e de modo novo, o seu poder-ser simesma. A angústia retira a presença de seu esquecimento no mundo da efetividade e a traz para a disposição de assumir o seu ser-possibilidade. Por isso, a angústia é uma provocação à presença, no sentido de ajuda-la a escutar a voz silenciosa do clamor que conclama a presença a ser si-mesma. Neste sentido, ela repõe a presença em sua finitude e a faz assumir-se em sua mortalidade. Ela instiga a presença para o salto da decisão que assume, no instante, o apelo para o poder-ser mais próprio, para a regência da propriedade. Ela deixa e faz a presença pressentir no nada da niilidade da facticidade do existir, o toque do estranho, ou seja, do outro do ente, o toque do ser. A vigência do nada, porém, não é, neste caso, a destruição da factualidade, nem a aniquilação do poder-ser, mas é, ao contrário, o deixar-ser si-mesmo. Por isso, o nada que desvela a estranheza de ser, é um nada positivo e criativo, pois dispõe a presença para ser-si-mesma e a desperta para o não-ente, para o ser em sua diferença.

O temor e a angústia mostram que a presença já está sempre disposta desta ou daquela maneira na abertura de sua existência. Mostram certa afinação ou desafinação com o mundo ou com o poder-ser-si-mesmo. A angústia pode ser interpretada, a partir da afinação com o mundo, como uma desafinação. Mas, olhando-se mais de perto, a angústia não é meramente uma desafinação com o mundo, mas é uma dissonância pela qual a presença pode se afinar mais propriamente com o nada de sua facticidade, que é o seu ter-sido originário. A angústia é, em sua dissonância, a oportunidade de uma afinação mais própria com o abismo, isto é, com o nada do fundamento da facticidade, ou seja, com o abismo do ser. Entretanto, uma vez que se dá o acorde ou o acordo com essa niilidade do abismo, a existência se afina com o seu poder-ser mais próprio, com o ser si-mesmo. A presença é, pois, reposta em sua essência de futuro.

A disposição diz o modo como a presença se acha e como ela vai. Ela se dá sempre como certa afinação com a facticidade do existir, ou seja, com o seu ter-sido lançado na existência, na abertura desvelada do ser. Ela entoa a compreensão enquanto ser para o poder-ser. Pela compreensão de si entoada desta ou daquela maneira com o poder-ser, a presença sabe “como vai”. Apenas, este saber não é explícito ou temático, mas é um saber em-sendo, um saber que é sabor da experiência. A experiência diz o modo como a presença é atingida de imediato em sua disposição e como ela deslancha em seu poder-ser. A experiência é o toque ou a percussão da facticidade, que ressoa e repercute na existência. Em toda a experiência o humor se põe numa certa afinação com a facticidade do existir. Por já ser sempre numa certa afinação é que o humor pode mostrar harmonia ou desarmonia, com esta facticidade, ou seja, se a presença vai bem ou vai mal, ou seja, se ela se acha em afinação com o poder-ser si-mesma ou em desafinação com ele. O humor, pois, diz o modo como a presença está disposta na existência, como ela se acha em sua facticidade e como ela vai em seu poder-ser, se ela deslancha ou se ela se obstrui os caminhos para o poder-ser si-mesma. Decisivo é se ela se afina com a facticidade (o ter-sido originário) e com o poder-ser (o porvir originário) (Heidegger, 1989, p. 137-144). O ser para o poder-ser, porém, se chama compreensão. Portanto, toda disposição já entoa e determina alguma compreensão (Heidegger, 1989, p. 132-127).

Compreensão não significa, aqui, conhecimento objetivo ou objetivante e nem mesmo conhecimento subjetivo ou reflexivo. Caso convenha falar de conhecimento, então há que se dizer que a compreensão é um conhecimento em-sendo, em existindo, um co-nascimento ou uma co-nascença com as possibilidades da existência. Compreender é, aqui, saber de si, saber como se vai, a quantas anda o si-mesmo. Trata-se de um conhecimento que é anterior a todo o reconhecimento. Trata-se de um saber que é sabor de experiência feita. Compreender é, aqui, existir. Isto significa: ser lançando-se para um poder-ser. O que está em jogo, portanto, no compreender não é o alcance de uma informação, nem de uma reflexão, mas o apropriar-se de um poder-ser. A compreensão é uma relação de ser com o próprio ser, que se dá no existir mesmo da presença. Ela é um lance que abre o poder-ser, que possibilita o poder-ser-si-mesma da presença, que deixa e faz deslanchar a existência na regência da propriedade. Enquanto abertura, a compreensão propriamente dita, isto é, a compreensão para o poderser mais próprio, destranca a existência e a libera para ser a aberta onde a verdade do ser se ilumina. Assim, a presença vem a si mesma, singularizando-se. O que está em jogo, portanto, na compreensão é o porvir da presença, a essência de futuro, em que repousa originariamente a humanidade do homem.

Contudo, de início e normalmente, a presença se move na incompreensão do poder-ser si-mesma. Absorvida nas ocupações e tomada pela familiaridade do mundo, ela se empenha sempre de novo em função da atualização das possibilidades de uso e desfrute. Ela se compreende, assim, a partir daquilo de que ela se ocupa, a partir de seus empreendimentos e negócios. Aparentemente ela está em função do futuro, mas este futuro é apenas o prolongamento da atualização. O cuidado apreensivo e aflitivo pelo futuro se baseia no afã do autoasseguramento das 
possibilidades de atualização das possibilidades de uso e desfrute. Ele se empenha todo em atender e providenciar as condições destas possibilidades. Os cálculos sobre as chances de realizar tal atendimento e providência caracteriza a expectativa deste modo de se relacionar com a existência. Contudo, este modo de ser ansioso não se relaciona com o futuro como futuro, quer dizer, o futuro que aí está em questão não é o porvir da presença, ou seja, o vir a si-mesma da presença, mas o prolongamento da atualização. Portanto, na compreensão das possibilidades de ocupação em que a presença se esquece de seu poder-ser mais próprio, vigora, na verdade, uma incompreensão, um trancamento para a regência da propriedade do si-mesmo. O cálculo das expectativas conta com todas as chances, só não conta com a morte. É que a morte apresenta-se como a possibilidade da impossibilidade (Heidegger, 1989, p. 46), ou seja, como aquela possibilidade latente, que é radical, pois é insuperável e irremissível, a possibilidade que anula todas as possibilidades. A morte revela assim a niilidade da existência, mostra o fundamento da facticidade como abismo e recolhe a presença na sua finitude.

A compreensão da mortalidade, portanto, ou seja, o ser para aquele poder-ser que nadifica todo o poder-ser, é um abismar-se no qual a presença se desvia do adiantarse e antecipar-se que prolonga a atualização no arrebatamento do mundo e no esquecimento do si-mesmo; mas é também, ao mesmo tempo, um abismar-se que reenvia a presença para assumir aquele adiantar-se e antecipar-se no qual a presença se destranca para o poder-ser si-mesma. A compreensão da mortalidade, portanto, enquanto possibilidade impossível se revela, paradoxalmente, como impossibilidade possível, ou seja, como impossibilidade possibilitadora do poder-ser si-mesmo. Com efeito, com a compreensão da mortalidade, a finitude urge da presença o bem-viver, contudo, não mais um bem-viver que é interpretado a partir das ocupações como uso e desfrute, mas um bem-viver que é interpretado a partir da obediência (ausculta) à voz silenciosa que conclama a presença para o poder-ser mais próprio. Assim, o abismar-se da compreensão da mortalidade se torna salto gracioso e gratuito da decisão, entendida não como escolha disso ou daquilo, mas como escolha do poder-ser si-mesmo. A compreensão da mortalidade, portanto, é o aguilhão que deixa e faz a presença abrir-se para o seu poder-ser si-mesma. Isto quer dizer: ela é a provocação para a singularização da presença e, nessa singularização, para assumir a pertença ao mistério do ser, cujo véu se dá como mortalidade da existência. O singular que a morte traz consigo é o fato de ela ser o convite para se deixar apropriar pela verdade do ser, tanto em sua dimensão de desvelamento (apolínea), quanto em sua dimensão de velamento (hermética). A morte revela o mistério da existência, ou seja, ela mostra que o desvelado se enraíza no velamento, que o aberto está radicado no ocluso. Ela é o supremo estranhamento da familiaridade do ser-no-mundo. Ela é o baú do nada, do não-ente, e, enquanto tal, a testemunha do ser em seu caráter abissal. Paradoxalmente, porém, a compreensão do caráter abissal do ser não retira da presença o seu poder-ser si-mesma, antes, é ela que lhe possibilita esta possibilidade. Ela liberta, no sentido de destrancar a presença para o seu poder-ser si-mesma, ou seja, para a regência da propriedade, que é o acontecer da pertença à verdade (desvelamento-velamento) do ser. Ela singulariza na solidão. Mas esta solidão é condição para toda e qualquer comunhão verdadeira.

Graças à solidão e à singularização que se abre com a compreensão da mortalidade da existência, a presença pode se tornar, de fato e propriamente histórica. Histórica se torna a presença não quando entra em cena no palco da "história mundial", a partir de seus feitos. Histórica se torna a presença quando seu existir se torna constante numa temporalidade originária. Originária é a temporalidade quando ela acontece a partir do porvir; quando o futuro deixa de ser o prolongamento da atualização e passa a ser a antecipação da liberdade do poder-ser; quando o passado deixa de ser esquecimento e passa a ser retomada da facticidade; quando o presente deixa de ser o atual e o atuante e passa a ser o instante. Só se torna histórica a presença que se recolhe no vigor do instante (Heidegger, 1989, p. 135).

Por instante entende-se aqui, porém, não o instantâneo, o fugaz momento, o agora do tic-tac do relógio. Instante é, aqui, a coincidência, o encontro, a identidade de futuro (como porvir, poder-ser, lance de abertura) e passado (como facticidade, ter-sido, ser-lançado). Este encontro, porém, se dá como decisão da presença, ou seja, como destrancamento da existência. Trata-se, porém, não da decisão como escolha disso ou daquilo, mas da decisão em que a presença se torna decidida, isto é, livre para o poder-ser si mesma e para assumir a facticidade abissal da existência. Instante é o advir da jovialidade de ser, que assume a abissalidade da existência como mistério da gratuidade. Instante é o momento azado, o kairós, da libertação e da maturação da presença na verdade do ser.

\section{Cuidado como Ser-com-o-Outro}

O mundo que se abre com a própria abertura da presença a partir da temporalidade é também e de modo igualmente originário o mundo da convivência, do sercom-os-outros (Heidegger, 1988, p. 168-178). Se factual e onticamente o outro pode faltar, estar ausente, fáctica e ontologicamente o outro é sempre presente, melhor, copresente. O ser-com não é o resultado da ocorrência de uma pluralidade de sujeitos. O ser-com é estrutura a priori da existência. Neste sentido, duas coisas que ocorrem aí ou que estão à mão não são propriamente uma com a outra. Neste contexto, só são um com o outro aqueles entes que são no modo de ser da presença, que igual- 
mente existem, e que compartilham do mesmo modo de ser-no-mundo.

Ser-com, enquanto a priori da facticidade, significa que o eu nunca precisa sair de si para entrar no mundo do outro. O ser-com determina, de antemão, que o eu já esteja desde sempre aberto para o outro, comunicado com ele, no mesmo mundo compartilhado da convivência. Trata-se de uma comunicação ontológico-existencial, isto é, uma comunicação que já acontece pelo simples fato de existir. Cada eu é o mundo, não um mundo fechado e sim um mundo aberto, pela disposição, pela compreensão e pela linguagem, onde já sempre se deu a abertura para o outro, que também é, igualmente, um constituidor e um configurador de mundo. Isso quer dizer: O mundo é, na verdade, um ser-com de muitos mundos.

O ser-com é o fundamento da relação eu-tu. Na verdade, a idéia de uma relação eu-tu ainda fica presa ao eu. O fundante da relação não é o eu, nem simplesmente o tu, mas a própria relação que se instaura em sua reciprocidade, a partir do ser-com: "Em vez de se falar sempre de uma chamada relação eu-tu seria melhor falar de uma relação tu-tu, porque eu-tu é sempre falado somente a partir de mim, enquanto na realidade é uma relação mútua” (Heidegger, 2001a, p. 224). O ser-com é também, por conseguinte, o fundamento do nós. O nós não resulta da soma ou do ajuntamento de eus. O nós se constitui a partir da comum-pertença dos humanos no ser-com, à medida que compartilham e coparticipam da existência, do mundo, da história. Portanto, por já ser no ser-com é que a presença sempre pode dizer: eu, tu, nós, vós. O dizer eu-tu ou o dizer nós-vós não depende tanto da ocorrência dos outros, nem do seu número, mas do fato de os outros serem encontrados num determinado tipo de relação, onde o cuidado se realiza desse ou daquele modo. É o como da relação que decide se há ou não uma relação eu-tu ou uma relação onde emerge propriamente o nós ou o vós. Na verdade, na impessoalidade do "todo o mundo", não se dá propriamente um eu, um tu, um nós, um vós. Todos são como "eles". Cada um é "os outros", um "a gente”. O tu não é encontrado como tu, mas como um isso. $\mathrm{O}$ nós também não acontece propriamente, pois não há lugar para a comunidade, apenas para a sociedade e o povo não pode ser povo, mas apenas massa. A pluralidade se dissolve na homogeneidade e não há mais propriamente um nós e um vós, pois tudo sucumbe na virulência da indiferença. O ser-com, fundamento do eu, tu, nós, vós, é, por sua vez, um ser-quem, são modalidades da "simesmidade” ou ipseidade. Contudo, a própria ipseidade, ou o ser-quem, já é sempre, a priori, relação. Ela é aquele modo de ser em que o que está em jogo é uma livre relação de ser com o ser, podendo-se, portanto, ganhar-se ou perder-se para a regência da propriedade.

A relação, portanto, está radicada no modo de ser da existência e requer ser compreendida em sua existencialidade. Como tal, ela não é objetiva, nem subjetiva, mas existencial. Qual sua essência?
A relação com algo ou alguém, na qual eu estou, sou eu. Entretanto, "relação” não deve ser objetivamente entendida aqui no sentido moderno, matemático de relação. A relação existencial não pode ser objetivada. Sua essência fundamental é ser aproximado e deixarse interessar, um corresponder, uma solicitação, um responder, um responder por base no ser tornado claro em si da relação (Heidegger, 2001a, p. 202).

Por conseguinte, a propriedade da relação depende do como da aproximação, do interesse, da correspondência, da solicitação, ou seja, no como da resposta à interpelação do outro, se esta resposta se libera para a liberdade da recepção e da doação e se clareia na disposição, na compreensão e na linguagem, ou se ela se tranca e não alcança transparência. Em sua estruturação, a relação com o outro é, portanto, regida pelo cuidado. Este pode acontecer, por exemplo, no modo privativo da indiferença da impessoalidade. Não só pode acontecer como acontece de início e na maior parte das vezes. Neste caso, o cuidado com o outro se priva de suas possibilidades, se tranca de antemão e permanece inteiramente opaco. Se, contudo, o cuidado com o outro acontece de fato, então ele oscila entre dois modos extremos: a negligência e a solicitude. A negligência se alimenta da desconfiança e da vontade de se sobrepor ao outro, dominando-o. A solicitude, por sua vez, pode se dar de modo impróprio e próprio. No modo impróprio, a solicitude busca substituir o outro na incumbência de seu cuidado. Ela retira do outro o poder-ser. No modo próprio, porém, a solicitude busca antecipar-se ao outro na incumbência de seu cuidado. Ela libera o outro para as incumbências de seu cuidado e apoia-o para que ele tenha a capacidade de assumir por si mesmo o seu poder-ser si-mesmo. O cuidado solícito é aquele em que alguém se antecipa no cuidado pelo outro, preocupando-se com ele numa atitude de consideração, não para lhe retirar a possibilidade do cuidado, mas para preparar-lhe os caminhos do assumir responsável pelo cuidado que é confiado e que lhe solicita e lhe reivindica como um apelo.

\section{Cuidado, Poder-Ser e Amor}

O que decide, por conseguinte do cuidado, é o como de seu poder-ser. O que está em jogo no cuidado é a capacidade de assumir positivamente as suas possibilidades de ser.

Assumir uma possibilidade significa ter sido atingido por ela, ter-se afeiçoado a ela, significa deixar-se conduzir pela sua tendência, fazer a sua travessia, deslanchar nela, crescendo no seu gosto. $\mathrm{O}$ gosto é o apego à possibilidade. Trata-se de um apego amoroso. $\mathrm{O}$ amor é o que possibilita a possibilidade. O amor é o que torna a possibilidade possível, isto é, capaz de ser. É o que a faz vingar, o que a faz deslanchar bem, é o que a faz consumar. 
Apegar-se a uma coisa” ou "pessoa” em sua essência, quer dizer: amá-la, querê-la. Pensando de modo mais originário, querer significa essencializa, dar essência. Esse querer é que constitui a própria essência do poder, que não somente pode realizar isso ou aquilo mas também deixa uma coisa "vigorar" em sua proveniência, isto é, deixa que ela seja. O poder do querer é aquilo em cuja "força" uma coisa pode propriamente ser. Esse poder é o "possível” em sentido próprio, a saber, aquilo cuja essência se funda no querer" (Heidegger, 1967, p. 29).

O amor, o querer como bem-querer, benevolência, é possibilidade da possibilidade da relação do ser-com, pois o amor é o que deixa-ser, isto é, o amor é o que presenteia essência, reconduzindo tudo e todos ao seu próprio. $\mathrm{O}$ amor, como possibilidade da possibilidade do relacionamento é o fundamento do cuidado. A in-sistência no sercom se dá, no seu sentido mais próprio, como diligência e dileção $($ diligo $=$ dilectio $=$ o lógos do relacionamento).

Entende-se, aqui, possibilidade como poder-ser, isto é, como capacidade e gosto de ser. Qual, porém, a relação entre poder e ser no poder-ser? Ser é, originariamente, poder. Poder como potência, isto é, como vigência e regência. A atuação do poder como vigência e regência se chama autoridade: a capacidade de fazer surgir, crescer e consumar o que está sendo (auctoritas, em latim, de augeo $=$ aumentar, fazer crescer). Com outras palavras, autoridade, enquanto dinâmica de atuação do poder, é a capacidade de fazer surgir a concreção do sendo, entendendo-se esta concreção como con-crescimento e cocriatividade. A potência do poder, que atua como autoridade, consiste, portanto, na positividade da liberdade, ou seja, na benignidade e cordialidade do deixar-ser. $\mathrm{O}$ ser enquanto poder coincide, nesse sentido, com o bem, melhor, "é" a bondade (bom-dade, o vigor de ser do bom) que, ao mesmo tempo, se difunde e se retrai. Difunde-se e irradia na sua magnanimidade e se retrai e se vela no pudor de sua simplicidade. É a grandeza em cuja magnanimidade tudo se ergue, cresce e amadurece, e, ao mesmo tempo, a simplicidade, que, em sua singeleza e humildade, já sempre se subtraiu, se retraiu e se velou. Por isso a autoridade do ser enquanto poder é suave. Seu vigor não se impõe. Sua força é silenciosa. Sua força é a fraqueza e a vulnerabilidade da ternura. É que o poder, na sua essência, não é outra coisa do que querer. Poder é querer. Isto quer dizer: potência é "volência", melhor, benevolência (a "volência”, a querença do bem), isto é, bem-querer que possibilita ser (Heidegger, 2001b, p. 180). Poder é querer, melhor, benquerença que presenteia o dom de ser. Trata-se, no entanto, de um presentear onde quem presenteia se oculta, se vela, se retrai no pudor de seu mistério. Por conseguinte, somente o amor é poder, é poder que possibilita ser.

Dileção e benevolência, por sua vez, se dão ao modo de ser da gratuidade (charis). A gratuidade é o modo de ser originário, fontal, do cuidado. É a origem, a fonte mesma de todo o sendo, que, brotando espontaneamente do fundo abissal do ser, deixa e faz ser o manancial, o fluxo, das possibilitações e realizações de todo o sendo. Intuímos isso, se tivermos presente o modo de ser, isto é, de vigorar da fonte. A fonte é origem de um manancial. Em seu efluir e fluir, as águas de um manancial brotam das entranhas da Terra, serpenteiam por entre as chapadas, traçam veredas, abrem paisagem, saltam de montanhas, rasgam regiões, tornando-se cada vez mais longínquas, acolhendo e recolhendo afluentes, alargando-se, aprofundando-se, até que, por fim, mergulham no grande mar. Por isso, o mar não é o outro da fonte. É antes, o aparecer da profundidade abissal da fonte, a vigência da generosidade originária da fonte. A fonte, porém, deixando e fazendo aparecer o manancial como tal, nunca a si mesma se mostra. Ela se retrai no vigor de sua renúncia. A fonte deixa e faz tudo aparecer, mas ela mesma se oculta, se esconde. Ela é como a protagonista do filme "A festa de Babette": celebração da pura gratuidade e graciosidade da vida. O brotar sem por quê nem para quê do ser. Ou então como a Rosa do poeta Ângelus Silesius (poeta do século XVII), cujo poema diz: "A rosa é sem por quê / floresce por florescer / não olha pra seu buquê / nem pergunta / se alguém a vê" (cfr. Silesius, 1992, p. 156).

A rosa sem porquê no orvalho matinal: a alegria acolhe o coração do mortal, no frescor, na claridade natal da inocência original. O mortal descansa, respira livre, regozija-se e renasce, na cercania da rosa, porque se recolhe e é acolhido no recato da natureza. A natureza da rosa de Angelus Silesius não é uma região do ente em oposição ao homem. É a nascividade, a liberdade do mistério que evoca o homem para a sua essência. É a própria vigência da presença que se abre como o frescor, a limpidez, a transparência e a graça de todas as coisas. É à mercê da liberdade do mistério que é o amor, a ternura, a benignidade, a paz, o bem, o rigor, a coragem, a sinceridade, a simplicidade. A liberdade do mistério, a nascividade é a jovialidade. A jovialidade é paciente, é benigna, ela não é invejosa, a jovialidade não é jactanciosa, não se ensoberbece. Não é descortês, não é interesseira, não se irrita, não guarda rancor: tudo desculpa, tudo crê, tudo espera, tudo tolera (1Cor 13,4-7) (Harada, s.d., p. 110).

A liberdade do mistério do ser, que é jovialidade e gratuidade, benevolência e dileção, estão evocadas na palavra que nomeia o ser enquanto ser, em Heidegger: Ereignis - o evento originário da apropriação, a regência originária e fontal da propriedade, que, no deixar-ser do ser, faz emergir cada coisa em seu próprio. Em sua forma originária, porém, Ereignis se dizia Eräugnis (Ur- äugnis) - o olhar originário, a mira originária. É o vigorar do instante (Augenblick), ou seja, do "piscar de olhos", em que a presença e o ser se encontram em seu copertencimen- 
to. $\mathrm{O}$ instante, em que a presença se abre, eclode, como a clareira do ser e, em sua liberdade e transparência, deixaser o próprio ser, consuma sua relação de ser com o ser, relação em que ela, originariamente, existe. Esta relação, porém, acontece originariamente desde o ser mesmo, que busca o homem como presença, como abertura. Trata-se da relação do ser para com o homem. O que está, pois, em jogo aqui é:

A relação elevada, na qual o homem está de pé, é a relação do Ser para com o homem, de tal modo que o Ser mesmo é esta relação, que puxa para si da essência do homem, enquanto aquela essência que está de pé nesta relação e, subsistindo nela, a custodia e a habita. No aberto desta relação do Ser para com a essência do homem, nós experimentamos o 'espírito' - ele é o que suavemente reina (das Waltende) vigorando a partir do Ser e, presumivelmente, em favor do Ser (Heidegger, 1994c, p. 7).

O que o pensamento, pela primeira vez, procurou expressar-se em Ser e Tempo, pretende alcançar, é algo de muito simples. Por ser simples, o Ser permanece misterioso, a proximidade calma de um vigor (Walten), que não se impõe à força. Essa proximidade se essencializa como linguagem.. (Heidegger, 1967, p. 54)

A palavra "ser" diz, aqui, a proximidade calma de um vigor (Walten), que não se impõe à força, mas que pede para ser recebida ao doar-se, que solicita, portanto, do homem, a disposição de dar ao doador a possibilidade de ser recebido. Suave é a regência do ser pois o relacionamento que ele é vigora como deixar-ser. Deixarser é libertar tudo quanto é para o vigor de sua própria essência. Deixar-ser é poupar (schonen), não no sentido de não usar, mas no sentido de cuidar com atenção e carinho. Deixar-ser é deixar repousar em sua própria essência, através do desvelo que custodia e salvaguarda (Heidegger, 1994c, p. 8).

"Agora, porém, justamente o ser, que todo ente, a cada vez e sempre de novo, deixa ser o que é e como é, é o libertador, o que deixa cada coisa repousar em sua essência, isto é, o que a cada coisa trata com cuidado e carinho" (Heidegger, 1994c, p. 9).

O homem existe. Isso significa: ele se ergue no espaço livre para a ressonância e a transparência do ser. Essa abertura da liberdade da ressonância e transparência em que o ser se confia ao homem e o homem se confia ao ser é a verdade. Verdade como o mistério do ser, isto é, o jogo amoroso de aparecer e retrair-se, de dar-se e retirar-se. Mas, no retrair-se e retirar-se, o ser não se desvia do homem, ele, antes, o atrai para dentro da intimidade de seu mistério, onde oculta as riquezas de seus dons. Esta insistência na verdade do ser é o cuidado (Sorge). O fundamento, pois, do cuidado é o relacionamento amoroso com o ser: filo-sofia (de philein, amar, tó sophon, o ser - como "um-tudo").
A relação própria, portanto, da presença com o ser, é amorosa, tanto da parte da presença para com o ser, como da parte do ser para com a presença. O ser se dá. Ele se entrega ao homem enquanto presença.

"Só enquanto se a-propria a clareira do Ser, é que o Ser se entrega, no que ele é propriamente, ao homem. Que, porém, o Da (lugar), a clareira, como Verdade do próprio Ser, se a-proprie, é destinação do próprio Ser. É o destino da clareira" (Heidegger, 1967, p. 60).

A entrega do ser ao homem, portanto, é destinação e isso perfaz a essência da história. Na destinação (Geschick) do ser está um presentear-se (sich schenken), o dar-se de si como dádiva. Pensar (denken) é, justamente, agradecer (danken) este presentear-se do ser. Ereignis significa, portanto, o recolhimento na unidade amorosa de ente, presença e ser.

Podemos dizer que a dinâmica dessa coincidência Dasein:Ser:ente, assim descrita de modo desengonçado, é o sentido propriamente dito da famosa "Khere" Heideggeriana, que não está a dizer a reviravolta da atividade literária e mutação ou transmutação ou evolução das ideias de Heidegger, mas sim a estruturação interna do ente ser. O Ser é: o Da do da-seiend, ao aparecer concreto no pudor da contenção das implicâncias do evento (Ereignis) como este próprio ente, aquele próprio ente, na "naturalidade" imediata. Na modéstia, no insignificante do dar-se simplesmente, como cada vez o próprio, como em sendo co-creação viva do pulsar tênue no nascer, crescer e consumar-se, como estremecer do viver, o cintilar "do olho" de cada coisa forma em composições estruturais, a imensa superfície aparentemente opaca e óbvia do cotidiano e comum, i. é, da maioria e do imediato do ente, sob cuja pele na tênue vibração, nesse da-seiend, se oculta o frêmito de vida do ser. Frêmito de vida do ser! É a vigência da Vida, que no abalo instantâneo, se revela superfície e abismo, serenidade e ira contida, ternura e vigor, nascimento e morte do estremecer e do abrir os olhos do renascimento, a se anunciar na penumbra do declínio ocidental e no cinzento claro do arrebol vindouro; é o incoativo retorno do outro início ao entardecer do primeiro início: o oriente do ocidente: esse sempre de novo e novo, cada vez da-seiend, i. é, o ente. (...) Então Ser, Tempo, Vida, coincide como, no e a partir do "ponto de salto", cuja mira, se dá na contenção e continência, no espanto e no pudor, no titubear de uma tênue vibração que ao assim se pôr constitui a empiria nasciva da aberta do retraimento na verdade do ser, acolhida e recolhimento da vigência do sabor humano, demasiadamente humano do "Homem humano", o ser-in de todas as coisas, a novidade do saber do concreto positivismo e da sua "lógica" analítica, cujo início longínquo ecoa e diz: to on legethai polakhos (Harada, 2004, p. 94-95). 
Por falar em oriente, terminamos esta reflexão com um poema oriental do sábio chinês Chuang-Tzu (Merton, 2002 p. 65-66). Parece evocar aquela proximidade calma de um vigor que não se impõe, a regência da propriedade, do evento-apropriador (Ereignis).

O sopro da natureza

Quando a Natureza magnânima suspira

Ouvimos os ventos

Que, silenciosos,

Despertam as vozes dos outros seres,

Soprando neles.

De toda fresta

Soam altas vozes. Já não ouvistes

O marulhar dos tons?

Lá está a floresta pendente

Na íngreme montanha:

Velhas árvores com buracos e rachaduras,

Como focinhos, goelas e orelhas,

Como orifícios, cálices,

Sulcos na madeira, buracos cheios d'água:

Ouve-se o mugir e o estrondo, assobios,

Gritos de comando, lamentações, zumbidos

Profundos, flautas plangentes.

Um chamado desperta o outro no diálogo.

Ventos suaves cantam timidamente,

E os fortes estrondam sem obstáculos.

E então o vento abranda. As aberturas

Deixam sair o último som.

Yu respondeu: Compreendo:

A música terrestre canta por mil frestas.

A música humana é feita de flautas e de instrumentos.

Que proporciona a música celeste?

Mestre Ki respondeu:

Algo está soprando por mil frestas diferentes.

Alguma força está por trás de tudo isso e faz

Com que os sons esmoreçam.

Que força é esta?

\section{Referências Bibliográficas}

Harada, H. (s/d). Espiritualidade Franciscana: o seguimento de Nosso Senhor Jesus Cristo - o modo de viver religioso. Manuscrito. Compilado por Fernando Mazon, s.l.

Harada, H. (2004). Heinrich Rombach: memória e gratidão. Scintilla. Revista de Filosofia e Mística Medieval [Faculdade de Filosofia São Boaventura]. 1 (2), 48-71.
Heidegger, M. (1967). Sobre o humanismo. Rio de Janeiro: Tempo Brasileiro.

Heidegger, M. (1977). A morada do homem. Revista Vozes, 71 (4), pp. 43-54.

Heidegger, M. (1988). Ser e Tempo (Parte I). Petrópolis: Vozes.

Heidegger, M. (1989). Ser e Tempo (Parte II). Petrópolis: Vozes.

Heidegger, M. (1994a). Zollikoner Seminare: Protokolle - Gespräche - Briefe. Frankfurt am Main: Vittorio Klostermann.

Heidegger, M. (1994b). Beiträge zur Philosophie (Vom Ereignis). Frankfurt am Main: Vittorio Klostermann

Heidegger, M. (1994c). Die Armut. In: Heidegger Studien, Vol. 10, 1994c, Berlin: Duncker \& Humblot.

Heidegger, M. (1999). Conferências e escritos filosóficos. São Paulo: Nova Cultural.

Heidegger, M. (2001a). Seminários de Zollikon. Petrópolis: Vozes.

Heidegger, M. (2001b). Ensaios e conferências. Petrópolis: Vozes / Bragança Paulista: EDUSF

Heidegger, M. (2003). A caminho da linguagem. Petrópolis: Vozes / Bragança Paulista: EDUSF.

Merton, T. (2002). A Via de Chuang Tzu. Petrópolis: Vozes.

Rombach, H. (1977). Leben des Geistes - Ein Buch der Bilder zur Fundamentalgeschichte der Menschheit. Freiburg: Herder.

Silesius, A. (1992). Il Pellegrino Cherubico. Torino: Paoline.

Marcos Aurélio Fernandes - Graduado em Filosofia pela Universidade São Francisco (1991), com Mestrado e Doutorado em Filosofia pela Pontifícia Universidade Antonianum (2000 e 2003). Atualmente é Professor Doutor da Universidade Católica de Brasília, lotado no Centro de Reflexão sobre Ética e Antropologia da Religião. Endereço Institucional: Universidade Católica de Brasília (Centro de Reflexão sobre Ética e Antropologia). QS 07 LOTE 01 EPCT Areal (Águas Claras). CEP 71966-700 - Brasilia, DF - Brasil. E-mail: framarcosaurelio@hotmail.com

Recebido em 12.05.11

Aceito em 23.10.11 